\title{
Role of Selected miRNAs as Diagnostic and Prognostic Biomarkers in Cardiovascular Diseases, Including Coronary Artery Disease, Myocardial Infarction and Atherosclerosis
}

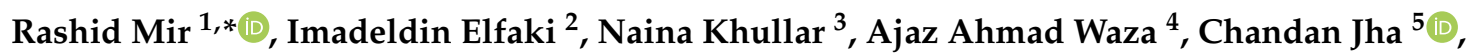 \\ Mohammad Muzaffar Mir ${ }^{6}{ }^{\circ}$, Shamsu Nisa ${ }^{7}$, Babar Mohammad ${ }^{8}$, Tahir Ahmad Mir ${ }^{9}$, Mohsin Maqbool ${ }^{10}$, \\ Jameel Barnawi ${ }^{1}$, Salem Owaid Albalawi ${ }^{11}$ and Faisel M. Abu-Duhier ${ }^{1}$
}

Citation: Mir, R.; Elfaki, I.; Khullar N.; Waza, A.A.; Jha, C.; Mir, M.M.; Nisa, S.; Mohammad, B.; Mir, T.A.; Maqbool, M.; et al. Role of Selected miRNAs as Diagnostic and

Prognostic Biomarkers in

Cardiovascular Diseases, Including Coronary Artery Disease, Myocardial Infarction and Atherosclerosis. J. Cardiovasc. Dev. Dis. 2021, 8, 22. https://doi.org/10.3390/jcdd8020022

Academic Editor: Gerhard Kostner

Received: 20 June 2020

Accepted: 15 February 2021

Published: 19 February 2021

Publisher's Note: MDPI stays neutral with regard to jurisdictional claims in published maps and institutional affiliations.

Copyright: (c) 2021 by the authors. Licensee MDPI, Basel, Switzerland. This article is an open access article distributed under the terms and conditions of the Creative Commons Attribution (CC BY) license (https:/ / creativecommons.org/licenses/by/ $4.0 /)$.
1 Prince Fahd Bin Sultan Research Chair, Department of Medical Lab Technology, Faculty of Applied Medical Sciences, University of Tabuk, Tabuk 71491, Saudi Arabia; jbarnawi@ut.edu.sa (J.B.); fabu-duhier@ut.edu.sa (F.M.A.-D.)

2 Department of Biochemistry, Faculty of Science, University of Tabuk, Tabuk 71491, Saudi Arabia; ielfaki@ut.edu.sa

3 Department of Zoology, Mata Gujri College, Fatehgarh Sahib, Punjab 140406, India; naina306@gmail.com

4 Department of Microbiology, Government Medical College (GMC), Srinagar, Kashmir, J \& K, Srinagar 190010, India; ajazahmad09@gmail.com

5 Department of Human Genetics, Punjabi University, Punjab, Chandigarh 147002, India; chandujha58@gmail.com

6 Department of Basic Medical Sciences (Biochemistry) College of Medicine, University of Bisha, Bisha 61922, Saudi Arabia; mirmuzaffar11@gmail.com

7 Department of Obstetrics \& Gynaecology, Sher-i-Kashmir Institute of Medical Sciences, J \& K, Srinagar, Soura 190011, India; drshamsu32@gmail.com

8 Department of Radiodiagnosis and Imaging, Government Medical College (GMC), Srinagar, Kashmir, J \& K, Srinagar 190010, India; babarmohmad000@gmail.com

9 Inderprastha Dental College \& Hospital, Ghaziabad, Uttar Pradesh, New Delhi 201010, India; tahirmir0814@gmail.com

10 Dana Farber Cancer Institute, Boston, MA 02215, USA; mohsin13r@gmail.com

11 Department of Cardiology, King Fahd Special Hospital, Tabuk 71491, Saudi Arabia; sal-wabsy@moh.gov.sa.com

* Correspondence: rashidmirtabuk@gmail.com

Abstract: Cardiovascular diseases are the leading cause of death worldwide in different cohorts. It is well known that miRNAs have a crucial role in regulating the development of cardiovascular physiology, thus impacting the pathophysiology of heart diseases. MiRNAs also have been reported to be associated with cardiac reactions, leading to myocardial infarction (MCI) and ultimately heart failure (HF). To prevent these heart diseases, proper and timely diagnosis of cardiac dysfunction is pivotal. Though there are many symptoms associated with an irregular heart condition and though there are some biomarkers available that may indicate heart disease, authentic, specific and sensitive markers are the need of the hour. In recent times, miRNAs have proven to be promising candidates in this regard. They are potent biomarkers as they can be easily detected in body fluids (blood, urine, etc.) due to their remarkable stability and presence in apoptotic bodies and exosomes. Existing studies suggest the role of miRNAs as valuable biomarkers. A single biomarker may be insufficient to diagnose coronary artery disease (CAD) or acute myocardial infarction (AMI); thus, a combination of different miRNAs may prove fruitful. Therefore, this review aims to highlight the role of circulating miRNA as diagnostic and prognostic biomarkers in cardiovascular diseases such as coronary artery disease (CAD), myocardial infarction (MI) and atherosclerosis.

Keywords: coronary artery disease; CAD; cardiovascular diseases; myocardial infarction; MI; acute myocardial infarction; AMI; microRNA; miRNA; miR 


\section{Introduction}

According to World Health Organization http:/ / www.who.int/cardiovascular_diseases (accessed date 2 October 2021), coronary artery disease (CAD) is the major cause of death in the world, amounting to about $31 \%$ of deaths worldwide. Thus, its earlier and authentic diagnosis can help prevent this disease and may aid in the treatment of patients. Many conventional diagnostic and prognostic biomarkers that can predict heart-related diseases are already available, which include the highly sensitive troponins, NT-pro BNP, left ventricular ejection fraction and the Systematic Coronary Risk Evaluation (SCORE) that provides a 10-year prediction of the risk associated with severe heart disease [1]. However, these methods serve well only in case of primary preventions and fail to give authentic results when applied to people who already have heart disease (preexisting heart patients). Thus, there is a need for better biomarkers that could work in case of secondary preventions. In the present context, an attempt has been made to evaluate various miRNAs as cardinal biomarkers for the diagnosis and prognosis of CAD [2]. MiRNA is a non-coding, small (up to 22 nucleotides long), single-stranded RNA molecule that is naturally equipped with properties of silencing RNA and regulating gene expression at the post transcriptional level. These miRNAs complementarily bind in the $3^{\prime}$ untranslated region $\left(3^{\prime}\right.$ UTR) of the target mRNA and cause downregulation. It has been reported that microRs constitute up to $5 \%$ of human genome, and that about one third of the protein-coding genes is regulated by miRNAs [3].

In the canonical pathway of miRNA biogenesis, the miRNAs are transcribed from DNA into primary microRs (pri-miRNAs) and catalyzed by RNA polymerase II (pol II), as depicted in Figure 1. The RNA polymerase III (pol III) can also catalyze the transcription of the miRNAs that are involved in cell cycle and growth. The pri-miRNAs are processed into the precursor-miRNA (pre-miRNA) by the microprocessor complex [4]. The microprocessor complex is composed of the ribonuclease III enzyme, Drosha and an RNA-binding protein DiGeorge syndrome critical region 8 (DGCR8), as depicted in Figure 1. The pre-miRNA is translocated to the cytoplasm by the exportin 5 (XPO5)/RanGTP complex [5]. In the cytoplasm the terminal loop of the pre-miRNA is removed by the RNase III endonuclease, Dicer, resulting in the formation mature miRNA duplex. The miRNAs regulate the gene expression via binding to specific sequences within the $3^{\prime}$ UTR of the target mRNAs. This binding results in deadenylation and decapping of the target mRNA and consequently the translation is repressed. The miRNAs also have been reported to bind the $5^{\prime}$ UTR of the target mRNAs, which causes silencing of the gene expression or bind the promoter region, which enhances the transcription.

The miRNAs have been known to play a crucial role in pathological processes relating to coronary artery disease [5]. They are potent biomarkers as they can be easily detected in body fluids (blood, urine, etc.) due to their remarkable stability and are present in apoptotic bodies and exosomes [6]. These are released as paracrine factors by both living and dying cardiomyocytes and thus these may act as effective biomarkers in predicting heart attack. Several studies have investigated the association between miRNA gene variations and susceptibility to various diseases, such as diabetes, atherosclerosis and coronary artery disease $[7,8]$. Several recent studies reported association of the genetic variants with different metabolic diseases in different genes, including the seed region of the miRNAs [8-14]. Our earlier reports indicated the potential association of the miRNAs gene polymorphism with the risk of developing CAD, as well as its association with different cardiometabolic phenotypes to stratify the CAD burden in the general population $[7,8,12,15,16]$. The review aims to present an authentic update on the molecular mechanisms of miRNA's role in the pathogenesis of $\mathrm{CAD}$ and its associated complications. It will also highlight the individual potential of different mRNAs as diagnostic and prognostic markers of these diseases. 


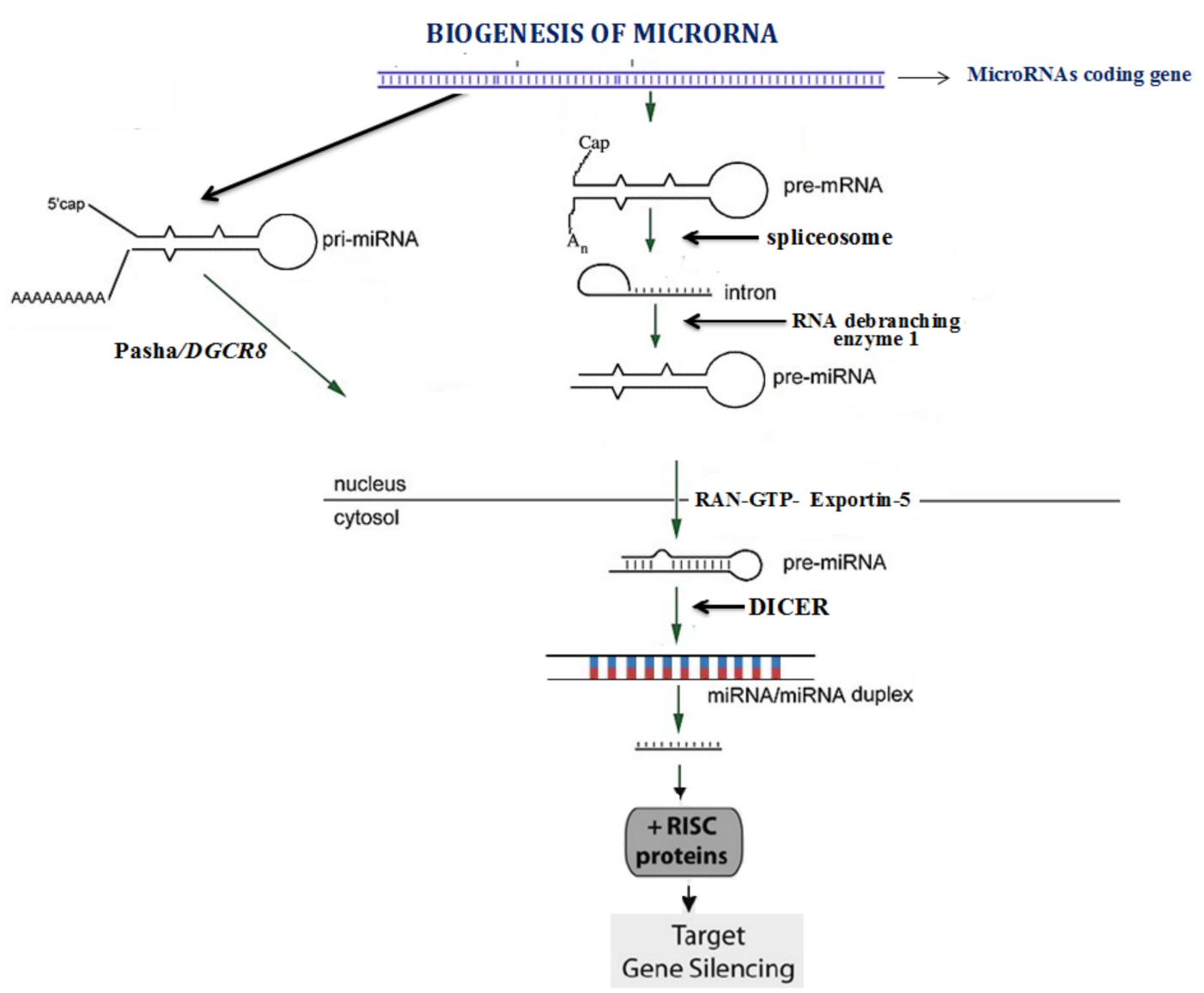

Figure 1. Biogenesis of microRNA.

\section{Role of miRNAs $19 b-3 p$ in CAD}

MiR-19b is located on chromosome 13 and is an important constituent of the miRNA17-92 cluster, comprising of miR-17, 18a, 19b, 20a and 92a. Studies have shown a decrease in the amount of miR-19b in serum as well as myocardium of cardiac patients than in controls [17]. Several studies reported an association of miR-19b deregulation with increased myocardial enzyme lysyl oxidase (LOX) enzyme expression. Cardiac function is directly affected by extracellular matrix (ECM) composition, and alterations of the ECM contribute to the progression of heart failure. It is indicated that excess synthesis and activation of LOX in HF patients increase collagen cross-linking, significantly increasing collagen resistance to degradation by matrix metalloproteinases (MMPs), leading to increased stiffness in left ventricular chamber and thus leading to diastolic dysfunction. Thus, a reduced miR$19 \mathrm{~b}$ expression leads to increased myocardial LOX protein and CCL and left ventricular stiffness in heart patients [18]. To date, only the ratio between C-terminal telopeptide of collagen type I to matrix metalloproteinase- 1 is an approved biomarker for myocardial fibrosis, but now circulating miR-19b could serve as a cardinal biomarker. Many lines of evidence justify their involvement in ageing-related heart failures. Its secretion rapidly increases during apoptosis and hypertrophy of the cardiomyocytes involving atrogin- 1 and MuRF-1 [19]. MiR-19b downregulates the expression of antihypertrophic factors Atrogin 1 and muscle ring finger protein 1 . It also causes hypertrophy by inducing NFAT (calcineurin/nuclear factor of Activated T cells) and P13K. It is confirmed in various studies pertaining to atherosclerosis that miR-19b suppresses peroxisome proliferator-activated receptor $\gamma$ coactivator $1 \alpha$ (PGC-1 $\alpha$ ), which leads to malfunctioning of endothelial cells [20]. It thus activates the accumulation of foam cells and macrophages; it further targets ATPbinding cassette transporter $\mathrm{A} 1$ (ABCA1) and causes development of aortic atherosclerosis. MiR-19b also targets pro-coagulant protein tissue factor (TF) as an antithrombotic agent, represses the $\alpha$-crystallin-B encoding gene and weakens the Bim gene (pro-apototic gene) 
expression, and thus promotes cell survival [21]. Furthermore, the miR-17-92 cluster (that includes miR-19b) promotes survival, activation and proliferation of $\mathrm{CD}^{+} \mathrm{T}$ cells and hence regulates heart-related disorders. It induces inflammation mediated by Th17 and is also known to inhibit Th2. MiR-19b suppresses the expression of the TGF $\beta$ RI and TGF $\beta$ RII genes, thus downregulating the fibrogenesis process [22]. MiR-19b is regulated by the cMyc gene [23].

\section{Role of miR-186-5p in CAD}

MiR-186, miR-132 and miR-150 are differentially expressed in patients with unstable angina (UA), patients with chest pain of non-cardiac origin and healthy controls, respectively. Experimental evidence shows that the relative levels of miR-186-5p increased significantly in serum and conversely decreased in myocardial tissue. MiR-186-5p has been shown to induce atherogenic lipid formation. It also increased the proinflammatory cytokines production for progression of atherosclerotic lesions, plaque vulnerability and lesions [24]. MiR-186-5p may also be involved in hypoxic response and glucose metabolism, leading to acute coronary syndrome; however, experimental confirmations are still pending. MiR-186-5p, miR-134-5p and miR-19b-3p are all reliable biomarkers in the sense that their levels are not affected significantly by anticoagulant heparin and medicines for AMI (nitrates, beta blockers, aspirin, etc.) [25]. All three of these miRNAs get upregulated in the early phase of AMI.

Some studies have verified that miR 186-5p shows its peak expression usually $4 \mathrm{~h}$ after AMI. Thus, these three miRNAs together compositely give more accurate result than acting individually. MiR-186-5p acts as target for numerous genes, out of which 15 genes regulate carbohydrate metabolism while others are involved in the HIF-1 signaling pathway; these exist in exosome-free forms. It was found out that miR-186-5p (amongst eight miRNAs) was a very reliable biomarker for CAD and is crucially associated with hypoxia [26]; it thus has the potential to be the most acceptable prognostic biomarker since its level alters post PCI to protect myocardial tissue, therefore offering an accurate prediction of heart health. MiR-186-5p (upregulation) is also known to prove productive during complete vascular obstruction when most of the miRNAs fail to predict the prognosis of patients [27].

\section{Role of miR-331 and miR-151-3p in CAD}

The miR-331 family constitutes a group of three miRNAs (miR-331, miR-331-3p and miR-331-5p). There is sufficient evidence to pillar the pathological as well as physiological role of the miR-331 family in context of vascular heart diseases [28]. The mechanisms how miR-331 executes the regulation of heart diseases will be elucidated. This biomarker would help in well-timed diagnosis of heart diseases and prove a promising contender in the therapeutic plan of action. In most of the studies, peripheral blood samples were worked on, which revealed that miR-331 and miR-151-3p were secreted outside of the myocardium and their levels were notably upregulated during ST-segment-elevation myocardial infarction (STEMI), which mostly is the case during vulnerable plaque rupture [29]. Atherosclerosis (narrowing of artery due to accumulation of plaque) occurs when cytokines, endothelial cells and vascular smooth muscle cells become dysfunctional. It is initiated by high cholesterol and is an inflammatory abnormality in the intima of the artery. This rupturing of atherosclerotic plaque leads to acute cardiovascular diseases. These vulnerable plaques (VPs) have a characteristic large necrosis core and flimsy fibrosis cap, which is the T lymphocytes' and macrophages' invasion site. Thus, infiltration of macrophages destabilizes the VPs while autophagy of these macrophages instead stabilizes plaques. These macrophages produce different growth factors, namely, interferon- $\gamma$ (IFN- $\gamma$ ), matrix metalloproteinase (MMPs), tumor necrosis factor (TNF- $\alpha$ ) and cytokines [30]. Thus, the best treatment is to stabilize these VPs [31]. Autophagy (destruction of damaged intracellular parts) helps prevent oxidative injury or cellular distress of plaque cells. Thus, the normal process of autophagy is vital and any disruption in autophagy may increase inflammation [32]. 
Atherosclerosis can be prevented by blocking phosphoinositide 3-kinase/protein kinase B (PI3K/Akt/mTOR), as depicted in Table 1. This (PI3K/AKT) signaling pathway stabilizes plaques by triggering autophagy. It has been reported that the miR-331 and miR151 inhibits (PI3K/AKT) the signaling pathway and thus keeps the VP intact [28,33]. Many studies have even unfolded the association of miR-331 and 151-3p with the JAK/STAT pathway. Upregulation of these miRNA upregulates SOCSI (suppressor of cytokine signaling protein, which inhibits both JAK (Janus kinase) and signal transducer but activates STAT transcription of nuclear genes [34].

Table 1. List of miR-19b-3p, 134-5p, 186-5p, 331 and 151-3p and their target genes and regulation factors, effects or pathways.

\begin{tabular}{|c|c|c|c|}
\hline microRNA & Target & Regulation Factors/Effects/Pathways & References \\
\hline $\operatorname{miR}-19 b-3 p$ & $\begin{array}{l}\text { PGC- } 1 \alpha, \text { ABCA1,TF } \\
\text { (procoagulant protein), Arigin } \\
\text { I, MuRF I (muscle RING } \\
\text { finger protein 1),TGF } \beta \text { RII }\end{array}$ & $\begin{array}{c}\text { Accumulation of foam cells and } \\
\text { macrophages, } \\
\text { calcineurin/NFAT PKC/TGF } \beta \text { signaling }\end{array}$ & [35] \\
\hline $\operatorname{miR}-134-5 p$ & $\begin{array}{l}\text { PI3K/Akt/mTOR, CREB } \\
\text { A12B (HSPA12B) }\end{array}$ & $\begin{array}{l}\text { Interferon- } \gamma(\mathrm{IFN}-\gamma) \text {, matrix } \\
\text { metalloproteinase (MMPs), tumor necrosis } \\
\text { factor (TNF- } \alpha \text { ) and cytokines }\end{array}$ & [36] \\
\hline miR-186-5p & $\mathrm{PI} 3 \mathrm{~K} / \mathrm{Akt} / \mathrm{mTOR}$ & $\begin{array}{l}\text { Interferon- } \gamma(\mathrm{IFN}-\gamma) \text {, matrix } \\
\text { metalloproteinase (MMPs), tumor necrosis } \\
\text { factor (TNF- } \alpha \text { ) and cytokines }\end{array}$ & [37] \\
\hline $\operatorname{miR}-331$ & SOCS1 & $\begin{array}{l}\text { JAK and signal transducers gets inhibited } \\
\text { STAT gets activated }\end{array}$ & [24] \\
\hline miR-151-3p & SOCS1 & $\begin{array}{l}\text { JAK and signal transducers gets inhibited } \\
\text { STAT gets activated }\end{array}$ & [25] \\
\hline
\end{tabular}

Legend: PGC-1alpha-peroxisome proliferator-activated receptor gamma coactivator 1-alpha; ABCA1-ATP binding cassette subfamily A member 1; TGF $\beta$ RII-transforming growth factor beta receptor II; NFAT—nuclear factor of activated T-cells; P13K/Akt/mTORphosphatidylinositol-3-kinase a serine/threonine protein kinase mammalian target of rapamycin; CREB—cAMP response element-binding protein; PKC - protein kinase C; SOCS1 - suppressor of cytokine signaling 1; HSPA12B-heat shock protein family A (Hsp70) member 12B.

\section{Role of miR-29a-3p in CAD}

MiR-29a-3p, a member of the miR-29 family, is encoded by a gene located on chromosome 7q32.3. The miR-29 isoforms have emerged as very important molecules that play diverse roles in the gamut of cardiovascular physiology and disease. Deng et al. [38] attributed a protective role to miR-29a-3p in TNF $\alpha$-induced endothelial dysfunction, which points to miR-29a-3p being a novel target for the prevention and treatment of atherosclerosis. MiR-29a-3p has emerged as a potential therapeutic target in the treatment of atrial fibrillation. Zhao et al. [39] reported that overexpression of miR-29a-3p causes the under expression of the CACNA1C gene (which codes for the $\alpha 1 \mathrm{c}$-subunit of the L-type calcium channel).

MiR-29a-3p has been shown to be overexpressed in conjunction with other miRNAs in diffuse myocardial fibrosis in patients with hypertrophic cardiomyopathy (HCM), thereby underscoring its role as a biomarker for diffuse myocardial fibrosis in HCM [40]. The members of the miR-29 family, including miR-29a-3p, have been reported to exhibit antifibrotic effects, thereby highlighting its role in post myocardial injuries [41]. MiR-29a-3p has been reported to offer a protective role against reactive oxygen species in patients with acute myocardial infarction. Zhang et al. [42] reported that levels of miR-29a-3p were significantly reduced in acute myocardial infarction patients and cardiac ischemic reperfusion (CIR)-injured mice, and this inhibition of miR-29a-3p induced reactive oxygen species (ROS) production and apoptosis in cardiomyocytes by targeting Bax. Another study found significant upregulation of miR-29a-3p in unstable angina, while no significant changes were observed in myocardial infarction and stable angina [43].

One of the critical contributions of miR-29a-3p is its role in the endothelial function in cardiometabolic disorders. Recently, the analogs of both microR-29a-3p and miR-29b-3p 
have been reported to improve endothelial function significantly in human type 2 diabetes mellitus arterioles, which imply a potential value for miR-29 mimics as a therapeutic agent for microvascular complications of type 2 diabetes mellitus as well as many other cardiovascular diseases where endothelial dysfunction plays a critical pathophysiological role [44]. Aberrant miR-29 isoform expression is involved in the development of cardiac fibrosis and congestive heart failure whereas a protective function of miR-29a-3p in endothelin-1 (ET-1)induced cardiomyocyte hypertrophy via inhibiting NFATc4 expression has been reported by $\mathrm{Li} \mathrm{M}$ et al. [45]. It has been reported that miR-29a-3p along with other miRNAs are associated with the prediction of sudden cardiac death in coronary heart diseases, which could help in the identification of high-risk patients with coronary heart diseases [38].

\section{Role of miR-574-3p and miR-574-5p in CAD}

The gene for miR-574-3p is located on chromosome $4 p 14$. The miR-574-3p has been seen to be overexpressed in CAD patients. The expression of both miR-574-3p and miR$574-5 p$ is upregulated in infarcted heart tissue compared with corresponding remote myocardium in human myocardial infarction, as well as with healthy human hearts [46]. MiR-574-3p has been strongly associated with promoting vascular smooth muscle cell growth in CAD progression $[47,48]$. In contrast, one previous study has not revealed any association between plasma miR-574-3p and cardiovascular disease [49].

The gene for miR-574-5p is located on chromosome $4 p 14$. The circulating levels of miR-574-5p are upregulated in CAD [49]. MicroR-574-5p expression is increased in myocardial infarcted as compared to healthy human heart tissue [50]. Recently miR-574$5 \mathrm{p}$ was significantly upregulated in patients with CAD as compared to healthy controls and also it was demonstrated that the miR-574-5p promoted vascular smooth muscle cell (VSMC) proliferation and inhibited apoptosis [47]. The abnormal proliferation of VSMCs promotes atherosclerotic plaque formation, whereas VSMC apoptosis may promote CAD-related inflammation. It has also been shown that the upregulation of miR-574-5p increased the VSMC growth while its downregulation inhibited the VSMC growth, thus strongly implicating miR-574-5p in CAD pathogenesis [51]. The role of miR-574-5p in the pathogenesis of CAD is proposed to involve the inhibition of ZDHHC14 (a tumor suppressor gene) expression. These reports and other studies suggest that miR-574-5p has potential value as a diagnostic marker and molecular therapeutic target in CAD [46,52].

\section{Role of miR-1 in CAD}

MicroR-1 is predominantly expressed in cardiac tissue and has been found to play an important role in developing cardiovascular diseases [53]. Two genes, namely, miR-1-1 and miR-1-2, are identical in nature and are located in two distinct chromosomal regions in the human genome, 20q13.33 and 18q11.2, which, respectively, encode miR-1 [54]. It has been reported that deletion of either miR-1-1 or miR-1-2 in mice produces similar phenotypes. Accordingly, a miR-1-2-null mouse develops different heart abnormalities, but generally survives as the miR-1-1 gene continuously produces some miR-1 [55]. Similarly; target deletion of miR-1-1 and miR-1-2 in mice produces fatal abnormalities and finally death [56]. The increased expression of miR-1 in the developing heart has been associated with reduced population of ventricular cardiomyocytes [57]. Therefore, a proper level of miR-1 is needed for normal functioning of the heart and any change in its expression level resulted in cardiac diseases. MiR- 1 has been associated with different cardiac diseases, such as arrhythmia, myocardial infarction, cardiac hypertrophy and heart failure. Several studies have reported a link between arrhythmia and an abnormal expression of miR-1. A decreased expression level of miR-1 (in the left atria) has been reported in patients suffering from persistent atrial fibrillation [58]. Similarly, severe arrhythmia has been reported with microR-1-2 deletion via Iroquois-class homeodomain protein (Irx5) [59]. A decreased expression of microR-1 has been reported in myocardial infarction (MI) patients and ischemia-reperfusion rats [60]. 
It has been reported that abnormal expression of miR-1 is associated with cardiomyocyte apoptosis and cardiac hypertrophy development. Sayed et al. [61] showed that the expression of miR-1 was immediately downregulated in cardiac hypertrophy model mice with aortic constriction. They also demonstrated that miR-1 regulates cardiac hypertrophy by negatively regulating the expression of the hypertrophy-associated genes, such as Acta1, Myh7 and Nppa, calmodulin, Mef2a, Ras GTPase-activating protein (RasGAP) and cyclindependent kinase 9. miR-1 is also associated with cardiac hypertrophy that is characterized by an increased cell size, heightened organization of the sarcomere and enhanced protein synthesis. It has been reported that miR-1 had significantly higher expression levels in non-ST-segment elevation myocardial infarction or ST-elevated myocardial infarctions than in unstable angina [27]. It has been reported that an increased level of miR-1 is a predictive biomarker for myocardial injury in older individuals [62]; however, this role as a biomarker is still debatable [63].

\section{Role of miR-208 in CAD}

The miR-208 family consists of miR-208a, miR-208b and miR-499 encoded by the myosin genes Myh6, Myh 7 and Myh7b. Tissue distribution of the miR-208 family is different: miR-208a is exclusively expressed in the heart, microR-208b in embryonic heart and miR-499 in skeletal muscles [64,65]. All three miRNAs are intrinsically regulated in a coordinated way. Overexpression of miR-208a has been found to stimulate the expression of miR-208b expression in normal adult mice heart, while silencing of microR-208a expression is associated with the decreased expression of miR-499 and miR-208b in rats [66]. There is strong evidence of a link between the dynamic expression of miR-208a, miR-208b and miR-499 and cardiovascular diseases [67], as depicted in the Table 2.

Table 2. Summary of the miR-208 family in cardiovascular disease.

\begin{tabular}{cccc}
\hline miRNAs & Species & Diseases & Phenotype \\
\hline & Human & AM & Over-expressed \\
& Rat & Myocardial injury & Over-expressed \\
Human & AMI and AP & Over-expressed \\
miR-208a & Human & HF & Over-expressed \\
& Rat & High-salt diet & Downregulated \\
& Human & DCM & Over-expressed \\
& H9C2 & Mechanical stretch & Downregulated \\
& Rat & AV shunt & Over-expressed \\
& Human & AMI & Over-expressed \\
\hline miR-208b & Human & AMI & Over-expressed \\
& Human & AMI & Over-expressed \\
& Human & Acute STEMI & Over-expressed \\
& Human & Acute STEMI and NSTEMI & Over-expressed \\
& Rat & High-salt diet & Over-expressed \\
& Mouse & TAB & Over-expressed \\
\hline Human & AMI and acute HF & Over-expressed \\
& Human & AMI & Over-expressed \\
& Human & Acute STEMI and NSTEMI & Over-expressed \\
& Human & AMI and AP & Over-expressed \\
& Human & AF & Over-expressed \\
& Human & HF & Over-expressed \\
& Human & Acute NSTEMI & Over-expressed \\
\hline
\end{tabular}

AMI: acute myocardial infarction; VF/VT: ventricular fibrillation/ventricular tachycardia; AV block: atrioventricular block; AF: atrial fibrillation; AP: angina pectoris; HF: heart failure; DCM: dilated cardiomyopathy; TAB: thoracic aortic banding; AV shunt: aorta-caval shunt; STEMI: ST segment elevated myocardial infarction; NSTEMI: non-ST-segment elevated myocardial infarction. 


\section{Role of miR-223 in CAD}

The miR-223 is located on the $\mathrm{X}$ chromosome within the arm q12 locus, and several transcription factor, viz., transcription factor PU.1, nuclear factor I-A (NFI-A) and CCAATenhancer-binding proteins- (C/EBP-) $\alpha$ and $\beta$, regulate its expression [68]. MiR-223 is found in the form of most abundant miRs in platelet and HDL and it is found as a form of an Ago2miR-223 complex in platelet microparticles (MPs). Human platelets activated by thrombin preferentially release Ago2-miR-223 complexes in MPs, which regulate the expression of endothelial mRNA FBXW7 and EFNA1 after being released from the MPs, showing that activated platelets deliver mRNA regulatory Ago2-miR complexes to other cells and regulate the expression of the endogenous genes in the recipient cell, such as endothelial cells (ECs) [69]. Vickers et al. found miRNAs in human high-density lipoprotein (HDL) and revealed a new mechanism of intracellular signaling through transported miRNAs to other cells [70]; also, the subjects with familial hypercholesterolemia of HDL-miRNA profiling were significantly different from those of the controls, which suggest that the quality as well as quantity of HDL has a most important role. Furthermore, one of the studies reported the anti-inflammatory function of HDL regulated by miRNAs, in which miR-223 in the HDL was transported to the ECs and decreased the expression of ICAM-1 in the ECs [71]. On the other hand, the same study revealed that HDL-miRNA from atherosclerotic patients induced differential gene expression in hepatocytes [72].

\section{Role of miR-155 in CAD}

The gene for miR-155 is located on chromosome 21q21.3 and its deregulation has been shown to be related to different forms of cancer, cardiovascular diseases and viral infections [73]. Zi-Liang Ye et al. studied the association between the expression of miR155 in peripheral blood $\mathrm{CD}^{+} \mathrm{T}$ lymphocytes and the level of serum interferon- $\gamma(\mathrm{IFN}-\gamma)$ concentration and the severity of CAD and concluded that the level of miR-155 and the level of IFN- $\gamma$ are closely correlated with the severity of CAD [74].

A recent study showed that both miR-155 and miR-221/222, which are highly expressed in endothelial cells (ECs), control Ets-1, induced by Ang II negatively. In addition, the overexpression of miR-155 or miR-221/222 in HUVECs downregulates the vascular cell adhesion molecule 1 (VCAM-1), monocyte chemoattractant protein-1 (MCP-1) and Fmsrelated receptor tyrosine kinase 1 (FLT-1) mRNA expressions caused by Ang II [75,76]. It has been reported that that the miR-155 regulates angiotensin II type 1 receptor expression in human umbilical vein endothelial cells [77]. Sun et al. indicated that miR-155 induced the adverse functions at ECs and atherosclerosis [78]. MiR-155 mediates endothelial inflammation and decreases the expression of the nuclear factor-kappa B (NF-B) p65 and adhesion molecules such as ICAM-1 or VCAM-1 in TNF-treated ECs [79]. It was suggested that in ECs miR-155 has protective functions. In patients with CAD, miR-155 circulation is significantly decreased as compared with healthy controls [80]. It has been found that eNOS is a direct target of miR-155 [78,81]. The inflammatory cytokines, including tumor necrosis factor- $\alpha$, increased miR-155 expression [82]. MiR-155 inhibition opposes TNF$\alpha$-induced downregulation of endothelial nitric oxide synthase, and the impairment of endothelium-dependent vasorelaxation [78]. MiR-155 has been described as a powerful marker for detecting CAD [83].

\section{Role of miR-423 in CAD}

MiR-423-5p is localized in chromosome 17q11.2 in the intron of the nuclear speckle splicing regulatory protein 1 gene [84]. It has been reported that there is a difference in the microR-423-5p trans-coronary gradients between patients with stable systolic heart failure and healthy controls, and it is suggested that miR-423-5p originates from heart tissues $[85,86]$. It has been shown that the microR-423-5p serum levels were significantly higher in patients with unstable angina pectoris than patients with stable angina pectoris and aortic stenosis $[87,88]$. It is suggested that the serum levels of miR-423-5p may reflect the stage of myocardial ischemia. Moreover, miR- $423-5 p$ has been suggested as a potential 
biomarker in cardiac failure and CAD [89,90]. It has been proposed that the miR-423-5p plasma levels are positively associated with the peripheral N-terminal (NT) pro-B-type natriuretic peptide (pro-BNP) [91]. The N-terminal (NT) pro-B-type natriuretic peptide is a marker of hemodynamic stress; its serum levels are increased in subjects with increased left ventricular mass, CAD and peripheral artery disease [92]. Furthermore, it has been shown that miR-423-5p predicts 3 months death in cardiogenic shock and that elevated miR-423$5 p$ is a marker of hypoperfusion [93]. Nabiałek et al. have also suggested circulating miR-423-5p as a potential early marker of myocardial infarction; they reported that the miR-423-5p plasma level is significantly increased in early AMI; then its level approaches normalization within the next $360 \mathrm{~min}$ [94]. Rizzacasa et al. have examined the expression profile of more than 80 microRNAs in the blood of CAD cases using real-time PCR and have shown that miR-423-5p exhibits different expression in plasma and peripheral blood mononuclear cell of subjects with stable and acute MI [95]. This pilot study stated the potential role of miR-423-5p as a new epigenetic biomarker in diagnosis and prognosis of CAD and AMI. However, a similar study reported that the serum level of miR-423 is reduced within the first day of the AMI and increased for 180 days after the AMI [96]. It has recently been indicated that miR-423-5p has been shown to directly regulate the O-GlcNAc transferase (OGT) gene in cardiomyocytes in a study conducted in mice [97]. Barkovskaya et al. reported that the GlcNAc transferase (OGT) catalyzes the addition of sugar $\beta$-N-acetylglucosamine (O-GlcNAc) sugar onto Ser and threonine residues of proteins substrate; the (O-GlcNAc) donor is the UDP-GlcNAc and also the OGT is essential for cell division and embryogenesis [98]. The expression of miR-423-5p inhibits of GlcNAc transferase expression and its downstream target, AMPK phosphorylation. Then, the apoptosis-promoting proteins, proteins p53 and caspase-3 will be upregulated, leading to an increased apoptotic rate of cardiomyocytes. Therefore, miR-423-5p transfection results in cardiomyocyte apoptosis [99]. It has been predicted that miR-423-5p may regulate the transcription factors involved in important physiological processes, such as proliferation and differentiation [95].

\section{Role of miR-133b in CAD}

In humans, three miR-133 genes, miR-133a-1, miR-133a-2 and miR-133b, are located on chromosomes 18, 20 and 6 respectively. miR-133 is highly expressed in myocardium and skeletal muscle, and is involved in the development, differentiation, survival and electrical conduction of cardiomyocytes [100]; it is also implicated in cardiac hypertrophy, cardiac fibrosis, cardiac hypertrophy and heart arrhythmia, and it has been reported that miR-133 targets genes involved in cardiac hypertrophy, such as RhoA, Cdc42, Nelf-A/WHSC2, MAPK, TGF $\beta /$ Smad and PI3K/Akt [101].

This study concluded that miR-133 is a regulator of cardiac hypertrophy and proposed a therapeutic application. miR-133a and $b$ have been reported to be upregulated in patients with CAD [102]. It has been reported that patients with left ventricle diastolic dysfunction have reduced miR-133 levels compared to healthy controls. Moreover, Kuwabara et al. [103] reported that the miR-133a level can be used a biomarker for cardiomyocytes necrosis; they also reported that miR-133a is elevated in cases with AMI, unstable angina pectoris and Takotsubo cardiomyopathy, and that the miR-133a level increased from damaged myocardium. An increased circulating miR-133a level in cases with ST-elevation myocardial infarction is correlated with decreased myocardial salvage, more infarction size, obstruction of the microvasculature and more distinctive reperfusion damage. Moreover, miR-133a and miR-133b have been described among the circulating miRNAs in various cardiovascular diseases [104]. Kumar et al. [105] compared the plasma levels of miR-133b in 15 pre-atherosclerotic normal coronary artery cases, 78 CAD subjects and 54 healthy controls, and reported that miR-133b is highly enriched in the myocardium. There is a negative correlation between the miR-133b plasma levels and the risk of CAD and therefore concluded that miR-133b is a potential biomarker to predict different stages of the CAD from the stage of pre-atherosclerosis to the advanced atherosclerotic condition. 


\section{Role of miR-30 in CAD}

The miR-30 (miR-30) family is one of main members of the miRNAs, consisting of five members and six mature miRNA molecules, which are miR-30a, miR-30b, miR-30c-1, miR-30c-2, miR-30d and miR-30e. These are encoded by six genes located at three different chromosomal regions: 1p34.2 (miR-30c and miR-30e), 6q13 (miR-30a) and 8q24.22 (miR$30 \mathrm{~b}$ and miR-30d). These six mature miRNAs possess a similar sequence near the $5^{\prime}$ end but differ by having a compensatory sequence near the $3^{\prime}$ end, which allow the miR-30 family members to perform different biological functions. The miR-30 members act as key regulators of complex biological processes in multiple CVDs, including ischemic heart disease, heart failure, hypertension and arrhythmias $[105,106]$. Furthermore, due to their presence in the circulation after the cardiovascular pathologies, they have been explored as novel biomarkers, particularly in the milieu of AMI and HF.

The miR-30 family is predominantly expressed in the heart, and its expression levels are decreased after cardiomyocyte hypertrophy and MI; they also play a role in ventricular remodeling (VR) $[107,108]$. The potential role of miR-30 in various physiological and pathological states has been observed and the increasing evidence shows that the miR-30 family also plays a crucial role in regulating autophagy, apoptosis, oxidative stress and inflammation. Interestingly, miR-30 released by cardiac fibroblasts acts as a paracrine mediator of cardiomyocyte hypertrophy; this makes the miR-30 family an attractive diagnostic and prognostic biomarker in the cardiovascular field. The miR-30 family can be easily assessed, with a robust stability in the circulating blood or plasma and with an excellent sensitivity $[109,110]$. The downregulation of the miR-30 family could be related to the rarefaction process and hypertension, making it a prognostic maker. Many studies have investigated the role of miR-30 in the pathogenesis of CVDs, making it one of the attractive diagnostic and prognostic biomarkers and giving a platform for the development of novel therapeutic strategies for CVDs [106,111].

\section{Role of microR-147b in CAD}

MiR-147b (miR-147b or hsa-miR-147b) is one of the key miRNAs found in humans and its gene is located on chromosome number 15. It is involved in posttranscriptional regulation of gene expression by affecting both the stability and translation of the target miRNAs. Studies demonstrated the participation of miR-147 in a negative feedback loop that is able to inhibit the proinflammatory response of macrophages to multiple TLR ligands. When dysregulated, its role has been seen in cancers, suggesting its oncogenic role; its role has also been confirmed in CVDs [112]. Chatterjee et al. reported a novel function of miR-147b in protecting barrier function in human vascular endothelial cells, which affects CVDs, and expression of microR-147 in CAD patients was reported less compared to the controls [113]. Yao-Meng et al. [109] reported lower expression miR-147 in patients with dilated cardiomyopathy (DCM) compared with control subjects, suggesting its role as a potential diagnostic biomarker [114]. Mingxia Gu et al. have shown that miR-147b inhibits viability and promotes cell apoptosis, which has a role in the pathogenesis of heart failure [115]. This makes miR-147b one of the important diagnostic biomarkers, as depicted in Table 3. 
Table 3. Diagnostic and prognostic role of various the miRNAs (miR-30, miR-147b and miR-638) associated with cardiovascular disorders (CVDs).

\begin{tabular}{cccc}
\hline miRNA ID & Change in Expression & Purpose & Pathology \\
\hline miR-30a & Increased & Diagnostic & MI \\
\hline miR-30b & Decreased & Diagnostic & AHF \\
\hline miR-30c & Decreased & Diagnostic & AMI \\
\cline { 2 - 4 } miR-30d & Decreased & Diagnostic & Fibrosis \\
\hline miR147 & Decreased & $\begin{array}{c}\text { Diagnostic and } \\
\text { prognostic }\end{array}$ & CHF \\
\hline miR-638 & Decreased & Diagnostic & AP \\
& Decreased & $\begin{array}{c}\text { Diagnostic and } \\
\text { prognostic }\end{array}$ & CS \\
\cline { 2 - 4 } & Increased & Diagnostic & hAVICs \\
\hline
\end{tabular}

\section{Role of miR-638 in CAD}

The miR-638 gene is located on chromosome 19 and it plays is an important miRNA, playing key roles in physiological processes in humans, such as development and transcriptional modification. The dysregulation of miR-638 has been seen in many pathologies, including cancer, lupus nephritis (LN) and CVDs. miR-638 participates in the pathophysiology of CVDs, such as stroke, and therefore is a potential biomarker of CVDs [116].

Luque et al. [112] showed lower serum miR-638 in symptomatic patients with carotid stenosis undergoing a carotid endarterectomy [117]. Serum miR-638 determination may also be useful for long-term management, monitoring and atherothrombotic plaque identification. So, the detection of miR-638 in serum may constitute a potential noninvasive biomarker associated with ischemic stroke, particularly in high cardiovascular risk individuals. Pan Li et al. showed that miR-638 is most significantly downregulated in human vascular smooth muscle cell (VSMC) proliferation [118]. Wong et al. showed miR-638 distinguished heart failure with reduced vs. preserved left ventricular ejection fraction and offers better diagnosis than N-terminal pro-brain natriuretic peptide [119]. Jiao et al. indicated that miR-638 is upregulated in human calcific aortic valves (hAVICs) compared with non-calcific valves and was significantly upregulated during hAVICs osteogenic differentiation [120]. This constitutes a promising noninvasive diagnostic as well as prognostic biomarker in cardiovascular pathologies risk.

\section{Conclusions}

In this review, we address the present state of understanding on the biogenesis, regulation and pathophysiological roles of miRNAs in cardiovascular diseases, and the potential future perspectives on their use as biomarkers and therapeutic agents. They are potent biomarkers as they can be easily detected in body fluids (blood, urine, etc.) due to their remarkable stability; they are also present in apoptotic bodies and exosomes. Existing studies suggest the role of microRs as valuable biomarkers. The miRNAs have many characteristics of an ideal biomarker, most notably their inherent stability and resilience, which accordingly make them promising candidates for the development of diagnostic tools and therapies for cardiovascular disease. A single biomarker may be insufficient to diagnose CAD or AMI; thus, a combination of different miRNAs may prove fruitful in the diagnosis and stratification of CVDs. Early diagnosis of CVD remains a challenge for clinicians; it is an important goal to reduce treatment-associated morbidity and mortality, and reach maximal long-term survival. Therefore, there is a pressing need to develop cost-effective, noninvasive and accurate screening of alternative diagnostic techniques for cardiovascular disease. Recent blood-based miRNA profiling studies, reporting their presence in serum and plasma, have generated the concept that circulating miRNAs hold much potential as novel noninvasive biomarkers for many diseases, including cardiovascular disease. 
Funding: This research received no external funding.

Acknowledgments: We are grateful to the from Abdel Mohsen Ibrahim Hashim Professor of English Literature, University of Tabuk, K.S.A. for helping us in grammatical and english lanuguage corrections.

Conflicts of Interest: Authors have declared that no competing interests exist.

$\begin{array}{ll}\text { Abbreviations } \\ \text { CAD } & \text { Coronary artery disease } \\ \text { CVD } & \text { Cardiovascular diseases } \\ \text { MCI } & \text { Myocardial infarction } \\ \text { AMI } & \text { Acute myocardial infarction } \\ \text { CVDs } & \text { Cardiovascular disorders } \\ \text { HDL } & \text { High-density lipoprotein } \\ \text { ECs } & \text { Endothelial cells } \\ \text { NFI-A } & \text { Nuclear factor I-A } \\ \text { MCP-1 } & \text { Monocyte chemoattractant protein-1 } \\ \text { FLT-1 } & \text { Fms-related receptor tyrosine kinase } 1 \\ \text { HUVECs } & \text { Human umbilical vein endothelial cells } \\ \text { VCAM-1 } & \text { Vascular cell adhesion molecule 1 } \\ \text { OGT } & \text { O-GlcNAc transferase } \\ \text { VR } & \text { Ventricular remodeling } \\ \text { DCM- } & \text { Dilated cardiomyopathy } \\ \text { hAVICs } & \text { Human calcific aortic valves } \\ \text { VSMC } & \text { Vascular smooth muscle cell } \\ \text { ECs } & \text { Endothelial cells } \\ \text { RasGAP } & \text { Ras GTPase-activating protein } \\ \text { HCM } & \text { Hypertrophic cardiomyopathy } \\ \text { ROS } & \text { Reactive oxygen species } \\ \text { MMPs } & \text { Matrix metalloproteinase } \\ \text { IFN- } \gamma & \text { Interferon- } \gamma \\ \text { TNF- } \alpha & \text { Tumor necrosis factor } \\ \text { VP } & \text { Vulnerable plaques } \\ \text { STEMI } & \text { ST-segment-elevation myocardial infarction } \\ \text { LOX } & \text { Lysyl oxidase } \\ \text { DGCR8 } & \text { DiGeorge syndrome critical region } 8 \\ \text { ICAM-1 } & \text { Intercellular adhesion molecule } 1 \\ \text { eNOS } & \text { Endothelial nitric oxide synthase } 3 \\ \text { MAPK } & \text { Mitogen-activated protein kinase } \\ \text { C/EBP } & \text { CCAAT-enhancer-binding proteins } \alpha \text { and } \beta \\ \text { CHF- } & \text { Congestive heart failure } \\ & \end{array}$

\section{References}

1. Khan, A.; Johnson, D.K.; Carlson, S.; Hocum-Stone, L.; Kelly, R.F.; Gravely, A.A.; Mbai, M.; Green, D.L.; Santilli, S.; Garcia, S.; et al. NT-Pro BNP Predicts Myocardial Injury Post-vascular Surgery and is Reduced with CoQ10: A Randomized Double-Blind Trial. Ann. Vasc. Surg. 2020, 64, 292-302. [CrossRef] [PubMed]

2. Naito, S.; Petersen, J.; Sequeira-Gross, T.; Zeller, T.; Reichenspurner, H.; Girdauskas, E. Circulating microRNAs vs. aortic diameter in bicuspid aortic valve aortopathy. Asian Cardiovasc. Thorac. Ann. 2020, 218492320927233. [CrossRef]

3. Bhat, A.A.; Younes, S.N.; Raza, S.S.; Zarif, L.; Nisar, S.; Ahmed, I.; Mir, R.; Kumar, S.; Sharawat, S.K.; Hashem, S.; et al. Role of non-coding RNA networks in leukemia progression, metastasis and drug resistance. Mol. Cancer 2020, 19, 57. [CrossRef]

4. Macfarlane, L.A.; Murphy, P.R. MicroRNA: Biogenesis, Function and Role in Cancer. Curr. Genom. 2010, 11, 537-561. [CrossRef]

5. Bartoszewski, R.; Sikorski, A.F. Editorial focus: Entering into the non-coding RNA era. Cell Mol. Biol. Lett. 2018, 23, 45. [CrossRef] [PubMed]

6. O'Brien, J.; Hayder, H.; Zayed, Y.; Peng, C. Overview of MicroRNA Biogenesis, Mechanisms of Actions, and Circulation. Front. Endocrinol. 2018, 9, 402. [CrossRef]

7. Mir, R.; Jha, C.K.; Elfaki, I.; Javid, J.; Rehman, S.; Khullar, N.; Banu, S.; Chahal, S.M.S. Incidence of MicroR-4513C/T Gene Variability in Coronary Artery Disease-A Case-Control Study. Endocr. Metab. Immune Disord. Drug Targets 2019, 19, 1216-1223. [CrossRef] 
8. Elfaki, I.; Mir, R.; Mir, M.M.; AbuDuhier, F.M.; Babakr, A.T.; Barnawi, J. Potential Impact of MicroRNA Gene Polymorphisms in the Pathogenesis of Diabetes and Atherosclerotic Cardiovascular Disease. J. Pers. Med. 2019, 9, 51. [CrossRef] [PubMed]

9. Elfaki, I.; Mir, R.; Abu-Duhier, F.M.; Jha, C.K.; Al-Alawy, A.I.; Babakr, A.T.; Habib, S.A.E. Analysis of the Potential Association of Drug-Metabolizing Enzymes CYP2C9*3 and CYP2C19*3 Gene Variations with Type 2 Diabetes: A Case-Control Study. Curr. Drug Metab. 2020, 21, 1152-1160. [CrossRef]

10. Elfaki, I.; Mir, R.; Almutairi, F.M.; Duhier, F.M.A. Cytochrome P450: Polymorphisms and Roles in Cancer, Diabetes and Atherosclerosis. Asian Pac. J. Cancer Prev. 2018, 19, 2057-2070. [CrossRef]

11. Jha, C.K.; Mir, R.; Elfaki, I.; Javid, J.; Babakr, A.T.; Banu, S.; Chahal, S.M.S. Evaluation of the Association of Omentin 1 rs2274907 A $>$ T and rs2274908 G>A Gene Polymorphisms with Coronary Artery Disease in Indian Population: A Case Control Study. J. Pers. Med. 2019, 9, 30. [CrossRef]

12. Mir, R.; Elfaki, I.; Jha, C.K.; Javid, J.; Rehman, S.; Banu, S.; Mir, M.M.; Babakr, A.T.; Chahal, S.M.S. Molecular Evaluation of MicroRNA-146 Gene Variability (rs2910164 C> G) and its Association with Increased Susceptibility to Coronary Artery Disease. Microrna 2020. [CrossRef] [PubMed]

13. Elfaki, I.; Mir, R.; Abu-Duhier, F.M.; Khan, R.; Sakran, M. Phosphatidylinositol 3-kinase Glu545Lys and His1047Tyr Mutations are not Associated with T2D. Curr. Diabetes Rev. 2020, 16, 881-888. [CrossRef]

14. Liu, X.; You, L.; Zhou, R.; Zhang, J. Significant association between functional microRNA polymorphisms and coronary heart disease susceptibility: A comprehensive meta-analysis involving 16484 subjects. Oncotarget 2017, 8, 5692-5702. [CrossRef]

15. Jha, C.K.; Mir, R.; Elfaki, I.; Khullar, N.; Rehman, S.; Javid, J.; Banu, S.; Chahal, S.M.S. Potential Impact of MicroRNA-423 Gene Variability in Coronary Artery Disease. Endocr. Metab. Immune Disord. Drug Targets 2019, 19, 67-74. [CrossRef]

16. Mir, R.; Jha, C.K.; Elfaki, I.; Rehman, S.; Javid, J.; Khullar, N.; Banu, S.; Chahal, S.M.S. MicroRNA-224 (rs188519172 A>G) Gene Variability is Associated with a Decreased Susceptibility to Coronary Artery Disease: A Case-Control Study. Microrna 2019, 8 , 198-205. [CrossRef]

17. Li, M.; Hu, X.; Zhu, J.; Zhu, C.; Zhu, S.; Liu, X.; Xu, J.; Han, S.; Yu, Z. Overexpression of miR-19b impairs cardiac development in zebrafish by targeting ctnnb1. Cell Physiol. Biochem. 2014, 33, 1988-2002. [CrossRef] [PubMed]

18. Kanuri, S.H.; Ipe, J.; Kassab, K.; Gao, H.; Liu, Y.; Skaar, T.C.; Kreutz, R.P. Next generation MicroRNA sequencing to identify coronary artery disease patients at risk of recurrent myocardial infarction. Atherosclerosis 2018, 278, 232-239. [CrossRef] [PubMed]

19. Song, D.W.; Ryu, J.Y.; Kim, J.O.; Kwon, E.J.; Kim, D.H. The miR-19a/b family positively regulates cardiomyocyte hypertrophy by targeting atrogin-1 and MuRF-1. Biochem. J. 2014, 457, 151-162. [CrossRef]

20. Navickas, R.; Gal, D.; Laucevicius, A.; Taparauskaite, A.; Zdanyte, M.; Holvoet, P. Identifying circulating microRNAs as biomarkers of cardiovascular disease: A systematic review. Cardiovasc. Res. 2016, 111, 322-337. [CrossRef] [PubMed]

21. Chen, C.; Ponnusamy, M.; Liu, C.; Gao, J.; Wang, K.; Li, P. MicroRNA as a Therapeutic Target in Cardiac Remodeling. BioMed Res. Int. 2017, 2017, 1278436. [CrossRef] [PubMed]

22. Tang, Y.; Zhang, Y.C.; Chen, Y.; Xiang, Y.; Shen, C.X.; Li, Y.G. The role of miR-19b in the inhibition of endothelial cell apoptosis and its relationship with coronary artery disease. Sci. Rep. 2015, 5, 15132. [CrossRef]

23. Liang, H.Z.; Li, S.F.; Zhang, F.; Wu, M.Y.; Li, C.L.; Song, J.X.; Lee, C.; Chen, H. Effect of Endothelial Microparticles Induced by Hypoxia on Migration and Angiogenesis of Human Umbilical Vein Endothelial Cells by Delivering MicroRNA-19b. Chin. Med. J. 2018, 131, 2726-2733. [CrossRef]

24. Zeller, T.; Keller, T.; Ojeda, F.; Reichlin, T.; Twerenbold, R.; Tzikas, S.; Wild, P.S.; Reiter, M.; Czyz, E.; Lackner, K.J.; et al. Assessment of microRNAs in patients with unstable angina pectoris. Eur. Heart J. 2014, 35, 2106-2114. [CrossRef] [PubMed]

25. Wang, K.J.; Zhao, X.; Liu, Y.Z.; Zeng, Q.T.; Mao, X.B.; Li, S.N.; Zhang, M.; Jiang, C.; Zhou, Y.; Qian, C.; et al. Circulating MiR-19b-3p, MiR-134-5p and MiR-186-5p are Promising Novel Biomarkers for Early Diagnosis of Acute Myocardial Infarction Cell Physiol. Biochem. 2016, 38, 1015-1029. [CrossRef] [PubMed]

26. Wang, F.; Long, G.; Zhao, C.; Li, H.; Chaugai, S.; Wang, Y.; Chen, C.; Wang, D.W. Plasma microRNA-133a is a new marker for both acute myocardial infarction and underlying coronary artery stenosis. J. Transl. Med. 2013, 11, 222. [CrossRef]

27. Widera, C.; Gupta, S.K.; Lorenzen, J.M.; Bang, C.; Bauersachs, J.; Bethmann, K.; Kempf, T.; Wollert, K.C.; Thum, T. Diagnostic and prognostic impact of six circulating microRNAs in acute coronary syndrome. J. Mol. Cell Cardiol. 2011, 51, 872-875. [CrossRef] [PubMed]

28. Horvath, M.; Horvathova, V.; Hajek, P.; Stechovsky, C.; Honek, J.; Senolt, L.; Veselka, J. MicroRNA-331 and microRNA-151-3p as biomarkers in patients with ST-segment elevation myocardial infarction. Sci. Rep. 2020, 10, 5845. [CrossRef]

29. Hopkins, P.N. Molecular biology of atherosclerosis. Physiol. Rev. 2013, 93, 1317-1542. [CrossRef]

30. Virani, S.S.; Alonso, A.; Benjamin, E.J.; Bittencourt, M.S.; Callaway, C.W.; Carson, A.P.; Chamberlain, A.M.; Chang, A.R.; Cheng, S.; Delling, F.N.; et al. Heart Disease and Stroke Statistics-2020 Update: A Report from the American Heart Association. Circulation 2020, 141, e139-e596. [CrossRef]

31. Razani, B.; Feng, C.; Coleman, T.; Emanuel, R.; Wen, H.; Hwang, S.; Ting, J.P.; Virgin, H.W.; Kastan, M.B.; Semenkovich, C.F. Autophagy links inflammasomes to atherosclerotic progression. Cell Metab. 2012, 15, 534-544. [CrossRef]

32. Yang, Y.; Yang, L.; Liang, X.; Zhu, G. MicroRNA-155 Promotes Atherosclerosis Inflammation via Targeting SOCS1. Cell Physiol. Biochem. 2015, 36, 1371-1381. [CrossRef] [PubMed] 
33. Zhai, C.; Cheng, J.; Mujahid, H.; Wang, H.; Kong, J.; Yin, Y.; Li, J.; Zhang, Y.; Ji, X.; Chen, W. Selective inhibition of PI3K/Akt/mTOR signaling pathway regulates autophagy of macrophage and vulnerability of atherosclerotic plaque. PLoS ONE 2014, 9, e90563. [CrossRef] [PubMed]

34. Yang, L.Y.; Song, G.L.; Zhai, X.Q.; Wang, L.; Liu, Q.L.; Zhou, M.S. MicroRNA-331 inhibits development of gastric cancer through targeting musashi1. World J. Gastrointest. Oncol. 2019, 11, 705-716. [CrossRef]

35. Qin, D.N.; Qian, L.; Hu, D.L.; Yu, Z.B.; Han, S.P.; Zhu, C.; Wang, X.; Hu, X. Effects of miR-19b overexpression on proliferation, differentiation, apoptosis and Wnt/beta-catenin signaling pathway in P19 cell model of cardiac differentiation in vitro. Cell Biochem. Biophys. 2013, 66, 709-722. [CrossRef]

36. Marfella, R.; Di Filippo, C.; Potenza, N.; Sardu, C.; Rizzo, M.R.; Siniscalchi, M.; Musacchio, E.; Barbieri, M.; Mauro, C.; Mosca, N.; et al. Circulating microRNA changes in heart failure patients treated with cardiac resynchronization therapy: Responders vs. non-responders. Eur. J. Heart Fail. 2013, 15, 1277-1288. [CrossRef]

37. Meder, B.; Keller, A.; Vogel, B.; Haas, J.; Sedaghat-Hamedani, F.; Kayvanpour, E.; Just, S.; Borries, A.; Rudloff, J.; Leidinger, P.; et al. MicroRNA signatures in total peripheral blood as novel biomarkers for acute myocardial infarction. Basic Res. Cardiol. 2011, 106, 13-23. [CrossRef] [PubMed]

38. Deng, X.; Chu, X.; Wang, P.; Ma, X.; Wei, C.; Sun, C.; Yang, J.; Li, Y. MicroRNA-29a-3p Reduces TNFalpha-Induced Endothelial Dysfunction by Targeting Tumor Necrosis Factor Receptor 1. Mol. Ther. Nucleic Acids 2019, 18, 903-915. [CrossRef]

39. Zhao, Y.; Yuan, Y.; Qiu, C. Underexpression of CACNA1C Caused by Overexpression of microRNA-29a Underlies the Pathogenesis of Atrial Fibrillation. Med. Sci. Monit. 2016, 22, 2175-2181. [CrossRef] [PubMed]

40. Fang, L.; Ellims, A.H.; Moore, X.L.; White, D.A.; Taylor, A.J.; Chin-Dusting, J.; Dart, A.M. Circulating microRNAs as biomarkers for diffuse myocardial fibrosis in patients with hypertrophic cardiomyopathy. J. Transl. Med. 2015, 13, 314. [CrossRef] [PubMed]

41. Kriegel, A.J.; Liu, Y.; Fang, Y.; Ding, X.; Liang, M. The miR-29 family: Genomics, cell biology, and relevance to renal and cardiovascular injury. Physiol. Genom. 2012, 44, 237-244. [CrossRef]

42. Zhang, L.; Zhang, J.; Tong, Q.; Wang, G.; Dong, H.; Wang, Z.; Sun, Q.; Wu, H. Reduction of miR-29a-3p induced cardiac ischemia reperfusion injury in mice via targeting Bax. Exp. Ther. Med. 2019, 18, 1729-1737. [CrossRef] [PubMed]

43. Yang, K.; Shen, Q.; Lei, S.; Lu, T.; Cai, X.; Guo, L.; Sun, G.; Lv, G.; Sun, X.; Chen, S. Identifying microRNA biomarkers and constructing microRNA-regulated networks in coronary artery diseases: A meta-analysis. Int. J. Clin. Exp. Med. 2019, 12, 2899-2911.

44. Widlansky, M.E.; Jensen, D.M.; Wang, J.; Liu, Y.; Geurts, A.M.; Kriegel, A.J.; Liu, P.; Ying, R.; Zhang, G.; Casati, M.; et al. miR-29 contributes to normal endothelial function and can restore it in cardiometabolic disorders. EMBO Mol. Med. 2018, 10, e8046. [CrossRef]

45. Li, M.; Wang, N.; Zhang, J.; He, H.P.; Gong, H.Q.; Zhang, R.; Song, T.F.; Zhang, L.N.; Guo, Z.X.; Cao, D.S.; et al. MicroRNA-29a-3p attenuates ET-1-induced hypertrophic responses in H9c2 cardiomyocytes. Gene 2016, 585, 44-50. [CrossRef]

46. Zhang, L.; Zhang, Y.; Xue, S.; Ding, H.; Wang, Y.; Qi, H.; Wang, Y.; Zhu, W.; Li, P. Clinical significance of circulating microRNAs as diagnostic biomarkers for coronary artery disease. J. Cell Mol. Med. 2020, 24, 1146-1150. [CrossRef]

47. Bostjancic, E.; Zidar, N.; Glavac, D. MicroRNAs and cardiac sarcoplasmic reticulum calcium ATPase-2 in human myocardial infarction: Expression and bioinformatic analysis. BMC Genom. 2012, 13, 552. [CrossRef]

48. Salinas, J.; Lin, H.; A parico, H.J.; Huan, T.; Liu, C.; Rong, J.; Beiser, A.; Himali, J.J.; Freedman, J.E.; Larson, M.G.; et al. Whole blood microRNA expression associated with stroke: Results from the Framingham Heart Study. PLoS ONE 2019, 14, e0219261. [CrossRef] [PubMed]

49. Zhou, J.; Shao, G.; Chen, X.; Yang, X.; Huang, X.; Peng, P.; Ba, Y.; Zhang, L.; Jehangir, T.; Bu, S.; et al. miRNA 206 and miRNA 574-5p are highly expression in coronary artery disease. Biosci. Rep. 2015, 36, e00295. [CrossRef]

50. Ku, T.; Li, B.; Gao, R.; Zhang, Y.; Yan, W.; Ji, X.; Li, G.; Sang, N. NF-kappaB-regulated microRNA-574-5p underlies synaptic and cognitive impairment in response to atmospheric PM2.5 aspiration. Part. Fibre Toxicol. 2017, 14, 34. [CrossRef]

51. Lai, Z.; Lin, P.; Weng, X.; Su, J.; Chen, Y.; He, Y.; Wu, G.; Wang, J.; Yu, Y.; Zhang, L. MicroRNA-574-5p promotes cell growth of vascular smooth muscle cells in the progression of coronary artery disease. Biomed. Pharmacother. 2018, 97, 162-167. [CrossRef] [PubMed]

52. Li, K.; Wei, P.; Qin, Y.; Wei, Y. MicroRNA expression profiling and bioinformatics analysis of dysregulated microRNAs in obstructive sleep apnea patients. Medicine 2017, 96, e7917. [CrossRef] [PubMed]

53. Li, J.; Dong, X.; Wang, Z.; Wu, J. MicroRNA-1 in Cardiac Diseases and Cancers. Korean J. Physiol. Pharmacol. 2014, 18, $359-363$. [CrossRef] [PubMed]

54. Tao, G.; Martin, J.F. MicroRNAs get to the heart of development. eLife 2013, 2, e01710. [CrossRef]

55. Mishima, Y.; Stahlhut, C.; Giraldez, A.J. miR-1-2 gets to the heart of the matter. Cell 2007, 129, 247-249. [CrossRef]

56. Heidersbach, A.; Saxby, C.; Carver-Moore, K.; Huang, Y.; Ang, Y.S.; de Jong, P.J.; Ivey, K.N.; Srivastava, D. microRNA-1 regulates sarcomere formation and suppresses smooth muscle gene expression in the mammalian heart. eLife 2013, 2, e01323. [CrossRef]

57. Zhao, Y.; Samal, E.; Srivastava, D. Serum response factor regulates a muscle-specific microRNA that targets Hand2 during cardiogenesis. Nature 2005, 436, 214-220. [CrossRef] [PubMed]

58. Girmatsion, Z.; Biliczki, P.; Bonauer, A.; Wimmer-Greinecker, G.; Scherer, M.; Moritz, A.; Bukowska, A.; Goette, A.; Nattel, S.; Hohnloser, S.H.; et al. Changes in microRNA-1 expression and IK1 up-regulation in human atrial fibrillation. Heart Rhythm. 2009, 6, 1802-1809. [CrossRef] 
59. Costantini, D.L.; Arruda, E.P.; Agarwal, P.; Kim, K.H.; Zhu, Y.; Zhu, W.; Lebel, M.; Cheng, C.W.; Park, C.Y.; Pierce, S.A.; et al. The homeodomain transcription factor Irx 5 establishes the mouse cardiac ventricular repolarization gradient. Cell 2005, 123, 347-358. [CrossRef] [PubMed]

60. Bostjancic, E.; Zidar, N.; Stajer, D.; Glavac, D. MicroRNAs miR-1, miR-133a, miR-133b and miR-208 are dysregulated in human myocardial infarction. Cardiology 2010, 115, 163-169. [CrossRef]

61. Sayed, D.; Hong, C.; Chen, I.Y.; Lypowy, J.; Abdellatif, M. MicroRNAs play an essential role in the development of cardiac hypertrophy. Circ. Res. 2007, 100, 416-424. [CrossRef] [PubMed]

62. Qipshidze Kelm, N.; Piell, K.M.; Wang, E.; Cole, M.P. MicroRNAs as predictive biomarkers for myocardial injury in aged mice following myocardial infarction. J. Cell Physiol. 2018, 233, 5214-5221. [CrossRef] [PubMed]

63. Kura, B.; Kalocayova, B.; Devaux, Y.; Bartekova, M. Potential Clinical Implications of miR-1 and miR-21 in Heart Disease and Cardioprotection. Int. J. Mol. Sci. 2020, 21, 700. [CrossRef] [PubMed]

64. Callis, T.E.; Pandya, K.; Seok, H.Y.; Tang, R.H.; Tatsuguchi, M.; Huang, Z.P.; Chen, J.F.; Deng, Z.; Gunn, B.; Shumate, J.; et al. MicroRNA-208a is a regulator of cardiac hypertrophy and conduction in mice. J. Clin. Investig. 2009, 119, 2772-2786. [CrossRef]

65. Ji, X.; Takahashi, R.; Hiura, Y.; Hirokawa, G.; Fukushima, Y.; Iwai, N. Plasma miR-208 as a biomarker of myocardial injury. Clin. Chem. 2009, 55, 1944-1949. [CrossRef] [PubMed]

66. Montgomery, R.L.; Hullinger, T.G.; Semus, H.M.; Dickinson, B.A.; Seto, A.G.; Lynch, J.M.; Stack, C.; Latimer, P.A.; Olson, E.N.; van Rooij, E. Therapeutic inhibition of miR-208a improves cardiac function and survival during heart failure. Circulation 2011, 124, 1537-1547. [CrossRef]

67. Huang, Y.; Li, J. MicroRNA208 family in cardiovascular diseases: Therapeutic implication and potential biomarker. J. Physiol. Biochem. 2015, 71, 479-486. [CrossRef]

68. Chen, C.Z.; Li, L.; Lodish, H.F.; Bartel, D.P. MicroRNAs modulate hematopoietic lineage differentiation. Science 2004, 303, 83-86. [CrossRef]

69. Laffont, B.; Corduan, A.; Ple, H.; Duchez, A.C.; Cloutier, N.; Boilard, E.; Provost, P. Activated platelets can deliver mRNA regulatory Ago2*microRNA complexes to endothelial cells via microparticles. Blood 2013, 122, 253-261. [CrossRef]

70. Vickers, K.C.; Palmisano, B.T.; Shoucri, B.M.; Shamburek, R.D.; Remaley, A.T. MicroRNAs are transported in plasma and delivered to recipient cells by high-density lipoproteins. Nat. Cell Biol. 2011, 13, 423-433. [CrossRef]

71. Tabet, F.; Vickers, K.C.; Cuesta Torres, L.F.; Wiese, C.B.; Shoucri, B.M.; Lambert, G.; Catherinet, C.; Prado-Lourenco, L.; Levin, M.G.; Thacker, S.; et al. HDL-transferred microRNA-223 regulates ICAM-1 expression in endothelial cells. Nat. Commun. 2014, 5, 3292. [CrossRef]

72. Li, S.; Zhu, J.; Zhang, W.; Chen, Y.; Zhang, K.; Popescu, L.M.; Ma, X.; Lau, W.B.; Rong, R.; Yu, X.; et al. Signature microRNA expression profile of essential hypertension and its novel link to human cytomegalovirus infection. Circulation 2011, 124, 175-184. [CrossRef]

73. Pueyo, M.E.; Gonzalez, W.; Nicoletti, A.; Savoie, F.; Arnal, J.F.; Michel, J.B. Angiotensin II stimulates endothelial vascular cell adhesion molecule-1 via nuclear factor-kappaB activation induced by intracellular oxidative stress. Arter. Thromb. Vasc. Biol. 2000, 20, 645-651. [CrossRef]

74. Ye, Z.L.; Lu, H.L.; Su, Q.; Li, L. Association between the level of CD4(+) T lymphocyte microRNA-155 and coronary artery disease in patients with unstable angina pectoris. J. Geriatr. Cardiol. 2018, 15, 611-617. [CrossRef] [PubMed]

75. Zhu, N.; Zhang, D.; Chen, S.; Liu, X.; Lin, L.; Huang, X.; Guo, Z.; Liu, J.; Wang, Y.; Yuan, W.; et al. Endothelial enriched microRNAs regulate angiotensin II-induced endothelial inflammation and migration. Atherosclerosis 2011, 215, 286-293. [CrossRef] [PubMed]

76. Zhan, Y.; Brown, C.; Maynard, E.; Anshelevich, A.; Ni, W.; Ho, I.C.; Oettgen, P. Ets-1 is a critical regulator of Ang II-mediated vascular inflammation and remodeling. J. Clin. Investig. 2005, 115, 2508-2516. [CrossRef] [PubMed]

77. Cheng, W.; Liu, T.; Jiang, F.; Liu, C.; Zhao, X.; Gao, Y.; Wang, H.; Liu, Z. microRNA-155 regulates angiotensin II type 1 receptor expression in umbilical vein endothelial cells from severely pre-eclamptic pregnant women. Int. J. Mol. Med. 2011, 27, 393-399. [CrossRef] [PubMed]

78. Sun, H.X.; Zeng, D.Y.; Li, R.T.; Pang, R.P.; Yang, H.; Hu, Y.L.; Zhang, Q.; Jiang, Y.; Huang, L.Y.; Tang, Y.B.; et al. Essential role of microRNA-155 in regulating endothelium-dependent vasorelaxation by targeting endothelial nitric oxide synthase. Hypertension 2012, 60, 1407-1414. [CrossRef]

79. Wu, X.Y.; Fan, W.D.; Fang, R.; Wu, G.F. Regulation of microRNA-155 in endothelial inflammation by targeting nuclear factor (NF)-kappaB P65. J. Cell Biochem. 2014, 115, 1928-1936. [CrossRef]

80. Fichtlscherer, S.; De Rosa, S.; Fox, H.; Schwietz, T.; Fischer, A.; Liebetrau, C.; Weber, M.; Hamm, C.W.; Roxe, T.; Muller-Ardogan, M.; et al. Circulating microRNAs in patients with coronary artery disease. Circ. Res. 2010, 107, 677-684. [CrossRef]

81. Evangelista, I.; Nuti, R.; Picchioni, T.; Dotta, F.; Palazzuoli, A. Molecular Dysfunction and Phenotypic Derangement in Diabetic Cardiomyopathy. Int. J. Mol. Sci. 2019, 20, 3264. [CrossRef]

82. Guo, Q.; Zhang, H.; Zhang, B.; Zhang, E.; Wu, Y. Tumor Necrosis Factor-alpha (TNF-alpha) Enhances miR-155-Mediated Endothelial Senescence by Targeting Sirtuin1 (SIRT1). Med. Sci. Monit. 2019, 25, 8820-8835. [CrossRef]

83. Faccini, J.; Ruidavets, J.B.; Cordelier, P.; Martins, F.; Maoret, J.J.; Bongard, V.; Ferrieres, J.; Roncalli, J.; Elbaz, M.; Vindis, C. Circulating miR-155, miR-145 and let-7c as diagnostic biomarkers of the coronary artery disease. Sci. Rep. 2017, 7, 42916. [CrossRef] [PubMed] 
84. Miyamoto, S.; Usami, S.; Kuwabara, Y.; Horie, T.; Baba, O.; Hakuno, D.; Nakashima, Y.; Nishiga, M.; Izuhara, M.; Nakao, T.; et al. Expression Patterns of miRNA-423-5p in the Serum and Pericardial Fluid in Patients Undergoing Cardiac Surgery. PLoS ONE 2015, 10, e0142904. [CrossRef]

85. Wang, X.; Dong, Y.; Fang, T.; Wang, X.; Chen, L.; Zheng, C.; Kang, Y.; Jiang, L.; You, X.; Gai, S.; et al. Circulating MicroRNA423-3p Improves the Prediction of Coronary Artery Disease in a General Population- Six-Year Follow-up Results from the China-Cardiovascular Disease Study. Circ. J. 2020, 84, 1155-1162. [CrossRef]

86. Goldraich, L.A.; Martinelli, N.C.; Matte, U.; Cohen, C.; Andrades, M.; Pimentel, M.; Biolo, A.; Clausell, N.; Rohde, L.E. Transcoronary gradient of plasma microRNA 423-5p in heart failure: Evidence of altered myocardial expression. Biomarkers 2014, 19, 135-141. [CrossRef]

87. Goren, Y.; Kushnir, M.; Zafrir, B.; Tabak, S.; Lewis, B.S.; Amir, O. Serum levels of microRNAs in patients with heart failure. Eur. J. Heart Fail. 2012, 14, 147-154. [CrossRef]

88. Tijsen, A.J.; Creemers, E.E.; Moerland, P.D.; de Windt, L.J.; van der Wal, A.C.; Kok, W.E.; Pinto, Y.M. MiR423-5p as a circulating biomarker for heart failure. Circ. Res. 2010, 106, 1035-1039. [CrossRef]

89. Romaine, S.P.; Tomaszewski, M.; Condorelli, G.; Samani, N.J. MicroRNAs in cardiovascular disease: An introduction for clinicians. Heart 2015, 101, 921-928. [CrossRef] [PubMed]

90. Yan, H.; Ma, F.; Zhang, Y.; Wang, C.; Qiu, D.; Zhou, K.; Hua, Y.; Li, Y. miRNAs as biomarkers for diagnosis of heart failure: A systematic review and meta-analysis. Medicine 2017, 96, e6825. [CrossRef] [PubMed]

91. Wang, W.; Gao, J.; Wang, F. MiR-663a/MiR-423-5p are involved in the pathogenesis of lupus nephritis via modulating the activation of NF-kappaB by targeting TNIP2. Am. J. Transl. Res. 2017, 9, 3796-3803.

92. Jouni, H.; Rodeheffer, R.J.; Kullo, I.J. Increased serum N-terminal pro-B-type natriuretic peptide levels in patients with medial arterial calcification and poorly compressible leg arteries. Arter. Thromb. Vasc. Biol. 2011, 31, 197-202. [CrossRef]

93. Jantti, T.; Segersvard, H.; Tolppanen, H.; Tarvasmaki, T.; Lassus, J.; Devaux, Y.; Vausort, M.; Pulkki, K.; Sionis, A.; Bayes-Genis, A.; et al. Circulating levels of microRNA 423-5p are associated with 90 day mortality in cardiogenic shock. ESC Heart Fail. 2019, 6, 98-102. [CrossRef]

94. Nabialek, E.; Wanha, W.; Kula, D.; Jadczyk, T.; Krajewska, M.; Kowalowka, A.; Dworowy, S.; Hrycek, E.; Wludarczyk, W.; Parma, Z.; et al. Circulating microRNAs (miR-423-5p, miR-208a and miR-1) in acute myocardial infarction and stable coronary heart disease. Minerva Cardioangiol. 2013, 61, 627-637.

95. Rizzacasa, B.; Morini, E.; Mango, R.; Vancheri, C.; Budassi, S.; Massaro, G.; Maletta, S.; Macrini, M.; D’Annibale, S.; Romeo, F.; et al. MiR-423 is differentially expressed in patients with stable and unstable coronary artery disease: A pilot study. PLoS ONE 2019, 14, e0216363. [CrossRef]

96. Zhou, S.S.; Jin, J.P.; Wang, J.Q.; Zhang, Z.G.; Freedman, J.H.; Zheng, Y.; Cai, L. miRNAS in cardiovascular diseases: Potential biomarkers, therapeutic targets and challenges. Acta Pharmacol. Sin. 2018, 39, 1073-1084. [CrossRef] [PubMed]

97. Luo, P.; He, T.; Jiang, R.; Li, G. MicroRNA-423-5p targets O-GlcNAc transferase to induce apoptosis in cardiomyocytes. Mol. Med. Rep. 2015, 12, 1163-1168. [CrossRef] [PubMed]

98. Barkovskaya, A.; Seip, K.; Hilmarsdottir, B.; Maelandsmo, G.M.; Moestue, S.A.; Itkonen, H.M. O-GlcNAc Transferase Inhibition Differentially Affects Breast Cancer Subtypes. Sci. Rep. 2019, 9, 5670. [CrossRef] [PubMed]

99. Aubrey, B.J.; Kelly, G.L.; Janic, A.; Herold, M.J.; Strasser, A. How does p53 induce apoptosis and how does this relate to p53-mediated tumour suppression? Cell Death Differ. 2018, 25, 104-113. [CrossRef]

100. Abdellatif, M. The role of microRNA-133 in cardiac hypertrophy uncovered. Circ. Res. 2010, 106, 16-18. [CrossRef]

101. Care, A.; Catalucci, D.; Felicetti, F.; Bonci, D.; Addario, A.; Gallo, P.; Bang, M.L.; Segnalini, P.; Gu, Y.; Dalton, N.D.; et al. MicroRNA-133 controls cardiac hypertrophy. Nat. Med. 2007, 13, 613-618. [CrossRef]

102. Gupta, S.K.; Bang, C.; Thum, T. Circulating microRNAs as biomarkers and potential paracrine mediators of cardiovascular disease. Circ. Cardiovasc. Genet. 2010, 3, 484-488. [CrossRef]

103. Kuwabara, Y.; Ono, K.; Horie, T.; Nishi, H.; Nagao, K.; Kinoshita, M.; Watanabe, S.; Baba, O.; Kojima, Y.; Shizuta, S.; et al. Increased microRNA-1 and microRNA-133a levels in serum of patients with cardiovascular disease indicate myocardial damage. Circ. Cardiovasc. Genet. 2011, 4, 446-454. [CrossRef] [PubMed]

104. Eitel, I.; Adams, V.; Dieterich, P.; Fuernau, G.; de Waha, S.; Desch, S.; Schuler, G.; Thiele, H. Relation of circulating MicroRNA-133a concentrations with myocardial damage and clinical prognosis in ST-elevation myocardial infarction. Am. Heart J. 2012, 164, 706-714. [CrossRef] [PubMed]

105. Kumar, D.; Narang, R.; Sreenivas, V.; Rastogi, V.; Bhatia, J.; Saluja, D.; Srivastava, K. Circulatory miR-133b and miR-21 as Novel Biomarkers in Early Prediction and Diagnosis of Coronary Artery Disease. Genes 2020, 11, 164. [CrossRef]

106. Mao, L.; Liu, S.; Hu, L.; Jia, L.; Wang, H.; Guo, M.; Chen, C.; Liu, Y.; Xu, L. miR-30 Family: A Promising Regulator in Development and Disease. BioMed Res. Int. 2018, 2018, 9623412. [CrossRef]

107. Akodad, M.; Mericskay, M.; Roubille, F. Micro-RNAs as promising biomarkers in cardiac diseases. Ann. Transl. Med. 2016, 4, 551. [CrossRef] [PubMed]

108. Zhang, X.; Dong, S.; Jia, Q.; Zhang, A.; Li, Y.; Zhu, Y.; Lv, S.; Zhang, J. The microRNA in ventricular remodeling: The miR-30 family. Biosci. Rep. 2019. [CrossRef]

109. Zhang, Q.; Ma, X.F.; Dong, M.Z.; Tan, J.; Zhang, J.; Zhuang, L.K.; Liu, S.S.; Xin, Y.N. MiR-30b-5p regulates the lipid metabolism by targeting PPARGC1A in Huh-7 cell line. Lipids Health Dis. 2020, 19, 76. [CrossRef] 
110. Fu, X.M.; Zhou, Y.Z.; Cheng, Z.; Liao, X.B.; Zhou, X.M. MicroRNAs: Novel Players in Aortic Aneurysm. BioMed Res. Int. 2015, 2015, 831641. [CrossRef]

111. Zaragosi, L.E.; Wdziekonski, B.; Brigand, K.L.; Villageois, P.; Mari, B.; Waldmann, R.; Dani, C.; Barbry, P. Small RNA sequencing reveals miR-642a-3p as a novel adipocyte-specific microRNA and miR-30 as a key regulator of human adipogenesis. Genome Biol. 2011, 12, R64. [CrossRef] [PubMed]

112. Xu, C.; Liu, J.; Yao, X.; Bai, Y.; Zhao, Q.; Zhao, R.; Kou, B.; Li, H.; Han, P.; Wang, X.; et al. Downregulation of microR-147b represses the proliferation and invasion of thyroid carcinoma cells by inhibiting Wnt/beta-catenin signaling via targeting SOX15. Mol. Cell Endocrinol. 2020, 501, 110662. [CrossRef]

113. Chatterjee, V.; Beard, R.S., Jr.; Reynolds, J.J.; Haines, R.; Guo, M.; Rubin, M.; Guido, J.; Wu, M.H.; Yuan, S.Y. MicroRNA-147b regulates vascular endothelial barrier function by targeting ADAM15 expression. PLoS ONE 2014, 9, e110286. [CrossRef]

114. Huang, Y.M.; Li, W.W.; Wu, J.; Han, M.; Li, B.H. The diagnostic value of circulating microRNAs in heart failure. Exp. Ther. Med. 2019, 17, 1985-2003. [CrossRef] [PubMed]

115. Gu, M.; Wang, J.; Wang, Y.; Xu, Y.; Zhang, Y.; Wu, W.; Liao, S. MiR-147b inhibits cell viability and promotes apoptosis of rat H9c2 cardiomyocytes via down-regulating KLF13 expression. Acta Biochim. Biophys. Sin. 2018, 50, 288-297. [CrossRef]

116. Yao, Y.; Suo, A.L.; Li, Z.F.; Liu, L.Y.; Tian, T.; Ni, L.; Zhang, W.G.; Nan, K.J.; Song, T.S.; Huang, C. MicroRNA profiling of human gastric cancer. Mol. Med. Rep. 2009, 2, 963-970. [CrossRef]

117. Luque, A.; Farwati, A.; Krupinski, J.; Aran, J.M. Association between low levels of serum miR-638 and atherosclerotic plaque vulnerability in patients with high-grade carotid stenosis. J. Neurosurg. 2018, 131, 72-79. [CrossRef] [PubMed]

118. Li, P.; Liu, Y.; Yi, B.; Wang, G.; You, X.; Zhao, X.; Summer, R.; Qin, Y.; Sun, J. MicroRNA-638 is highly expressed in human vascular smooth muscle cells and inhibits PDGF-BB-induced cell proliferation and migration through targeting orphan nuclear receptor NOR1. Cardiovasc. Res. 2013, 99, 185-193. [CrossRef]

119. Wong, L.L.; Armugam, A.; Sepramaniam, S.; Karolina, D.S.; Lim, K.Y.; Lim, J.Y.; Chong, J.P.; Ng, J.Y.; Chen, Y.T.; Chan, M.M.; et al. Circulating microRNAs in heart failure with reduced and preserved left ventricular ejection fraction. Eur. J. Heart Fail. 2015, 17, 393-404. [CrossRef] [PubMed]

120. Jiao, W.; Zhang, D.; Wang, D.; Xu, R.; Tang, L.; Zhao, M.; Xu, R. MicroRNA-638 inhibits human aortic valve interstitial cell calcification by targeting Sp7. J. Cell Mol. Med. 2019, 23, 5292-5302. [CrossRef] 